\title{
Dr. S. van Mesdagkliniek: van bajes naar forensisch psychiatrisch ziekenhuis
}

\section{H. Siebering*}

De Dr. S. van Mesdagkliniek kent als gebouw een rijke historie. Het oorspronkelijke gebouw dateert uit de jaren $1882-1883$. Wanneer men aan de Hereweg voor de oude hoofdingang staat, kan men boven de grote poort met de zware, massieve houten deuren dit ook vermeld zien. Het toenmalige gebouw is gebouwd als een cellulaire gevangenis, bestemd voor recidiverende beroeps- en gewoontemisdadigers. De stichtingskosten bedroegen rond de fl. $800.000,=$.

In 1952 werd op 27 juni de strafgevangenis te Groningen tevens aangewezen als 'Noodasiel voor psychopaten'. De reden hiervoor was de grote toename van het aantal TBR-gestelden in de na-oorlogse jaren, het gebrek aan capaciteit in de particuliere inrichtingen en in de tot dan enige rijksinrichting: Rijksinrichting Veldzicht. Daar kwam nog bij, dat de particuliere inrichtingen geneigd waren om bij voorkeur de beter gemotiveerde, minder agressieve en mindere gevaarlijke patiënten op te nemen. Er was dus behoefte aan een degelijk en goed beveiligd gebouw. Vanaf dat moment werden er naast degenen die tot gevangenisstraf waren veroordeeld eveneens ter beschikking van de regering gestelden opgenomen. Deze situatie heeft ongeveer 10 jaar bestaan.

Rond 1961 werd het gebouw uitsluitend voor 'psychopathen' aangewezen en werd dit het 'Rijksasiel Dr. S. van Mesdag'.

\footnotetext{
* H. Siebering is stafmedewerker Juridische Zaken Dr. S. van Mesdagkliniek. De presentatie werd gezamenlijk verzorgd door H. Siebering en A. Warnaar, voormalig Hoofd Onderzoek en Ontwikkeling Dr. S. van Mesdagkliniek.
} 
Vanwege de zeer bijzondere bouwkundige situatie van het gebouw, werden vervolgens met name die TBR-gestelden opgenomen, die als bijzonder 'vlucht- en/of gemeengevaarlijk' werden gekarakteriseerd.

Op 5 april 1962 kreeg de kliniek uiteindelijk de naam, die tot op heden, haar het meest bekend heeft gemaakt: 'Dr. S. van Mesdagkliniek'.

De naam van de 'bajes' werd veranderd, maar daarmee veranderde de populatie nog niet. Op de verschillende afdelingen nam weliswaar het aandeel van psychopathen gestaag toe, maar er waren, zeker in de overgangfase ook nog andere gedetineerden in het gebouw, die niet onder deze categorie moeilijke mensen wilden vallen of daarmee 'onder een noemer (stempel) geschoven' wilden worden.

De naamwijzigingen maakten dus nog niet dat de problemen voor de kliniek-leiding van de baan waren. Het gebouw was een bajes en er diende het nodige te gebeuren teneinde een behandelklimaat te creëren. De nieuwe bewoners begonnen zich te realiseren, dat zij patiënten waren geworden, wat tot grote spanningen aanleiding gaf. Er volgde een moeilijke en roerige periode. De behandeling veranderde en deskundigen deden hun intrede. De patiënten vreesden (niet geheel ten onrechte, zoals later blijkt) een langer verblijf. Bovendien was de omschakeling van cellulair verblijf naar verblijf in een groep op een woonafdeling voor zowel de patiënten als voor het personeel een 'aardverschuiving'. Deze onzekerheden en spanningen leidden tot een tweetal ernstige uitbarstingen in 1963 en 1964, waarbij personeelsleden gegijzeld werden en er grote vernielingen werden aangericht. Deze incidenten maakten nog eens extra duidelijk dat het gebouw nauwelijks aan de eisen van zijn bestemming beantwoordde. De ontwikkeling van nieuwbouwplannen kwam hierdoor in een stroomversnelling.

\section{Eerste fase nieuwbouw}

Hoewel er in de loop van de daarop volgende jaren meerdere verbouwingen plaatsvonden, bleef tot eind jaren zestig nadrukkelijk het karakter van een gevangenis in stand. Toen werd er gestart met de eerste fase van een beoogde volledige nieuwbouw —een maquette is nog altijd aanwezig — door de oostvleugel van de kruisgevangenis te slopen en aan die zijde van de oude gevangenis een laagbouw complex te realiseren. Gestart werd met de bouw van het arbeidstherapiegebouw, gesitueerd aan de kant van het Sterrenbos. 
Vervolgens kwamen er ruimten voor de directie, administratie. Daarna volgden een sporthal, kantine, ruimten voor onderwijs en andere therapieën. Het eind van de eerste fase werd gekenmerkt door de sluiting van de oude toegangspoort aan de Hereweg en ingebruikname van de ingang aan de Engelse Kamp (1976).

Ook werden het Huis van Bewaring / Gevangenis en de Mesdagkliniek door muren met elkaar verbonden en ging de keuken van de kliniek de maaltijden voor de beide inrichtingen verzorgen. De beide justitiële instellingen hebben sedertdien op meerdere vlakken met elkaar te maken. Zo zijn we elkaar tot hulp ingeval van een calamiteit of indien er evacuatie zou moeten plaatsvinden van TBS -gestelden of gedetineerden. Daarnaast is er verwevenheid ten aanzien van de nutsvoorzieningen en vindt er daar waar er aanleiding toe is op het personele vlak collegiaal overleg plaats.

\section{Tweede fase nieuwbouw}

Alvorens men de tweede fase van de nieuwbouw kon starten, welke bestond uit de algehele sloop van de het gevangenisgebouw en het realiseren van een nieuw bewonerscomplex, sloeg de bezuiniging toe. Gevolg was dat de nieuwbouwplannen telkenmale uitgesteld werden. Uiteindelijk zou het tot begin 1994 duren dat de spade de grond inging voor de ' 2 e fase' . Het uitgangspunt hierbij was volledig anders. Het ging nu om uitbreiding van de opnamecapaciteit. En, hoewel men aanvankelijk het oude gevangeniscomplex nog wilde afstoten, werd al snel de behoefte duidelijk om dit gebouw toch te handhaven. Wel werd het reeds vele jaren afgekeurde gebouw grondig onderhanden genomen. De oude cellen werden vergroot en aangepast aan de eisen van de tegenwoordige tijd. Alle verblijven kregen een sanitaire ruimte. De tijd van beddenpan en waterkan is dan eindelijk verleden tijd.

De nieuwbouw is gebouwd volgens een beproefd ontwerp, dat we ook zien in de bouw van de gevangenissen van Lelystad en Almere. De bouw moet goedkoop zijn en dient vrij eenvoudig aanpasbaar te zijn aan een bestemmingwijziging, naar bijvoorbeeld een gevangenis. Daarbij heeft het ministerie zelf niet de gelden beschikbaar en het gebouw wordt dan ook evenals een aantal andere inrichtingen van Justitie gebouwd door een financier, PLC. Dit consortium is eigenaar van het pand en Justitie least het. Voor de gebruiker, de kliniek, levert dit wel de nodige problemen op, daar er extra 
overleg nodig is voor veranderingen van gebouwelijke situaties die wel passen in een gevangenis maar ons inziens niet thuishoren in een TBSinstelling.

Zo wilden wij in plaats van een schaamschot, klapdeurtjes hebben voor de sanitaire hoek. In een gevangenis is een gedetineerde alleen in zijn verblijf. Bij ons kan hij op zijn kamer bezoek ontvangen, dat dan ook gebruik maakt van het daar aanwezige sanitair. Een schaamschot zou in onze ogen onvoldoende recht doen aan de privacy. Deze 'correctie' voor alle 120 verblijven ging ruim een ton meer kosten en het vergde de nodige overredingskracht het toch gedaan te krijgen.

Ook het verschil in denken van een beheersmatige aanpak naar een behandelingsgerichte is goed waarneembaar in de bouw. Het 'oude' deel van het gebouw kent massieve ijzeren deuren en weinig glas. De toegang tot de afdelingen is via het vlak, de centrale plek van de kliniek.

De kleine ramen die het daglicht toelaten zijn afgeschermd met tralies en de verwarming geschiedt door dikke buizen die door de verblijven lopen. Ook de kleuren in het gebouw stammen uit de jaren zeventig: bruintinten en gebroken wit en pastelkleuren op de afdelingen.

Kijkend naar het 'nieuwe' deel, zien we veel glas in de deuren, puien en in de verblijven. Het buitenlicht kan ruimschoots binnentreden. De tralies en massieve deuren zijn verruild voor veiligheidsglas en deuren met glas. Verder is wit de kleur die alom aanwezig is. De afdelingen komen uit op gangen, die verbonden zijn met een centrale gang naar het plein, het nieuwe centrum van de kliniek. Op het plein zijn ook een aantal algemene voorzieningen getroffen, zoals een zithoek en een speelgelegenheid voor kinderen die meegekomen zijn met bezoekers. Ook bevindt zich een klein maar goed geoutilleerde (SRV-) winkel op het plein, zodat de winkelwagen niet meer via de sluizen naar een wandelplaats gemanoeuvreerd hoeft te worden.

Verder zijn er in verband met de toegenomen patiëntencapaciteit (120) in de nieuwbouw een aantal voorzieningen gecreëerd, zoals een zwembad, nieuwe ruimten voor muziektherapie, creatieve therapie, psychomotore therapie (met klimwand), een afdeling vorming en een totaal vernieuwde bibliotheek. Daarbij is de bibliotheek direct naast (en verbonden met) de afdeling vorming en onderwijs gesitueerd, waardoor er sprake is van een optimale samenwerking tussen deze beide afdelingen. Aanpassing van de arbeidstherapie was niet nodig, daar deze afdelingen in de eerste fase reeds toegesneden waren op een toegenomen populatie. Wel dienden er aanpassingen en herschikking van het therapie-aanbod plaats te vinden, daar de groei nu groter was geworden, van rond de negentig naar honderd twintig patiënten. 
Mede onder druk van deze groei vond een heroverweging plaats ten aanzien van individuele therapie naar (waar mogelijk) arbeidstherapie in kleinere groepjes. Ook de arbeid als middel om bij de problematiek van een patiënt te komen wordt losgelaten en er wordt voorzichtig weer productiegericht gewerkt: als arbeidsgewenning of als leerproces (scholing).

Voor de realisatie van de nieuwbouw heeft de kliniek wel haar voetbalveld moeten inleveren; daarvoor in de plaats heeft men een kleiner kunstgrasveld teruggekregen, met daarbij een zandbak voor bezoekers met kinderen.

Met de groei van de kliniek is in de loop der tijd ook de populatie TBRgestelden gegroeid: van rond de 50 verpleegden in 1976, 68 per 1 augustus 1986, tot ruim 180 mannelijke TBS-gestelden nu.

De Van Mesdagkliniek is een Rijksinrichting en is dus een overheidsinstelling, in tegenstelling tot de particuliere TBS -inrichtingen, die via overeenkomsten gebonden zijn aan de afspraken die men gemaakt heeft met het Ministerie van Justitie. Deze laatste instellingen zijn nog weer onder te verdelen in inrichtingen, die volledig gericht zijn op justitie en instellingen die, als onderdeel van een grotere VWS-instelling, een TBS kliniek -(afdeling) kennen.

\section{Interne indeling van de kliniek}

De kliniek heeft in de loop van de jaren de diverse afdelingen verschillend gerubriceerd. Enerzijds werd daarbij gekeken naar de beveiliging en anderzijds naar de verschillende wijze van bejegening van de bewoners op een afdeling. Daarbij dient in gedachte gehouden te worden dat de maatregel van de TBS formeel in de eerste plaats een beveiligingsmaatregel is. Maatschappijbeveiliging staat voorop bij de oplegging van de maatregel.

De behandeling, die plaatsvindt binnen de sterk beveiligde omgeving, is echter van essentieel belang in het gehele traject en is gericht op vermindering van de delictgevaarlijkheid. De kliniek onderscheidt hiertoe de volgende afdelingen:

Very intensive care afdelingen (VIC)

Dit zijn afdelingen voor maximaal vijf patiënten, met een hoge mate van beveiliging zowel ten aanzien van personeel, als ook materieel en met een 
strak regiem en zeer strenge veiligheidsregels. De beveiliging wordt individueel op de patiënten toegesneden. Indien daartoe aanleiding is kan de mate van structuur worden aangepast. Een plaatsing op een dergelijke afdeling kan niet zomaar geschieden. De in de wet vastgelegde criteria zijn:

-bescherming van de maatschappij tegen de grote mate van delictgevaarlijkheid;

-risico voor orde en veiligheid binnen de kliniek;

-afwending van ernstig gevaar voor de gezondheid van de betrokken patiënt.

Iedere zes maanden dient er in ieder geval bezien te worden of voortzetting van het verblijf op de afdeling noodzakelijk is. Hierover wordt een beslissing genomen die beklagwaardig is en juridisch getoetst kan worden.

De verblijven op deze afdelingen zijn een keer zo groot als die op de overige afdelingen. Dit heeft ondermeer te maken met het feit, dat zonodig patiënten gedurende 22 uur kunnen worden ingesloten in hun verblijf. Hoewel dit in de praktijk nauwelijks gebeurt, moet de voorziening daarop wel aangepast zijn. De patiënten kunnen zich, in beginsel alleen begeleid, buiten de afdeling begeven om aan activiteiten elders in de kliniek deel te nemen.

Intensive care afdelingen (IC)

Deze afdelingen herbergen maximaal elf patiënten. Extra materiële beveiliging is hier niet aan de orde en ook de mate van begeleiding is duidelijk beperkter dan op de VIC-afdelingen. Men wordt geacht zelfstandiger te kunnen functioneren en zelf problemen of knelpunten aan de orde te kunnen stellen bij de sociotherapeuten.

Via een mentorsysteem is er uiteraard wel aandacht voor de individuele patiënt. De verblijven op deze afdelingen zijn niet overdreven ruim. Het is ook de bedoeling dat men niet te veel op zijn verblijf zit. Deelname aan het groepsgebeuren op de afdeling (en daarbuiten) is van groot belang om inzicht te krijgen in het gedrag van betrokkenen teneinde de delictgevaarlijkheid te kunnen inschatten.

\section{Psychose afdelingen}

Deze afdelingen zijn gebouwelijk en qua uitvoering hetzelfde als de ICafdelingen. Het verschil zit in de wijze van bejegening. Er is sprake van een zeer gestructureerde situatie ten aanzien van de dagelijkse gang van zaken, waarvan nauwelijks wordt afgeweken. Er is gedurende de dag een extra personeelslid aanwezig. Het personeel van de afdeling neemt zelf actief deel 
aan de diverse activiteiten. De intensiteit van de contacten is daardoor groter dan elders in de kliniek.

\section{Resocialisatie afdeling}

Het resocialisatietraject is voor een aantal patiënten lang en moeizaam. Voor anderen gaat het snel. Voor plaatsing op deze afdeling dient een resocialisatieplan aanwezig te zijn. Deze afdeling is gerealiseerd in het oude directiedeel van de gevangenis, direct achter de oude voorpoort. Het aanvankelijke idee om de in- en uitgang van deze afdeling te realiseren aan de Herewegzijde werd door verhoging van de beveiliging naar aanleiding van een geslaagde ontvluchting, getorpedeerd.

De patiënten van deze afdeling dienen gebruik te maken van de toegang aan de Engelse Kamp, waardoor ze noodzakelijkerwijs door een deel van het beveiligd circuit moeten. Dit is een situatie waarin het gebouw en behandelingsidee niet met elkaar stroken, maar de beveiligingseis de doorslag geeft.

\section{Transmurale voorziening}

Aan de Hereweg zijn een tweetal (directie-)woningen zodanig verbouwd, dat daar ruimte is voor een viertal patiënten, die niet in staat zijn om de stap naar een zelfstandig bestaan in de maatschappij te maken. Ten einde deze patiënten voor te bereiden op een plaats binnen een bepaalde vorm van begeleid wonen, zijn deze voorzieningen gerealiseerd. De begeleiding is teruggebracht tot ongeveer twee uur per dag.

\section{Wooncentrum}

Het wooncentrum is een afdeling, waarin de nadruk niet meer zozeer ligt op behandeling maar op beheersing. Afhankelijk van de behoefte is er een behandelaanbod. Er verblijven patiënten, die geringe mogelijkheden hebben, daar de mate van beveiliging die ze nodig hebben zodanig is dat er buiten de kliniek geen voorzieningen zijn waar ze terecht kunnen. Pedoseksuelen, ongewenste vreemdelingen die niet terug kunnen of willen naar het land van herkomst zijn ondermeer aangewezen op deze afdeling. Het team van deze afdeling heeft allerlei activiteiten en mogelijkheden ontwikkeld, vooral binnen de beveiliging van de kliniek. 


\section{Gebouw versus behandeling}

Het feit dat de kliniek gevestigd is in een pand bestaande uit onderdelen uit 1883, 1976, 1995 en dat de start ligt in een afdeling van een gevangenis, maakt al dat de gebouwelijke gegevenheden nadrukkelijk mede de behandelingsmogelijkheden bepalen. Gedachten omtrent hoe een afdeling er idealiter uit zou moeten zien werden beperkt door de vorm en bouwwijze. Dit geldt ook voor de ideeën die later opgeld deden omtrent sociotherapie en therapeutisch klimaat.

Waren de personeelskamers in de oudbouw aan het eind van de afdeling gesitueerd, in de nieuwbouw bevinden deze zich in het midden van de afdeling en zijn zij ook ingebouwd in de afdeling. De contacten en interacties met de patiënten konden daardoor directer plaatsvinden.

Binnen het totale pand werken tegenwoordig ruim 400 personeelsleden (inclusief part-timers) op 18 afdelingen, verdeeld over een tweetal divisies. Te weten een divisie persoonlijkheidsgestoorden en een psychose-divisie. In totaal zullen er op (korte) termijn maximaal rond de 180 patiënten verblijven.

\section{Tot slot}

Het oude deel van het pand kan gekenschetst worden als een statig, grimmig gebouw met torentjes, dat eruit ziet als een onneembare vesting. Daartegenover staat het nieuwste bouwdeel, modern met grote vensters, zonder tralies: een forensisch psychiatrisch ziekenhuis. 


\section{Literatuur}

1. Informatie - Introduktie boekje: Dr. S. van Mesdagkliniek, Engelse Kamp 5, Groningen, interne publicatie, N. Oeloff e.a., mei 1977.

2. Van Mesdagkliniek in Groningen, zwaarst beveiligde TBR-inrichting van Nederland, uit 'Kijk op het Noorden', november/december 1986.

3. Behandelen in onvrijheid, 25 jaar Dr. S. van Mesdagkliniek, onder redactie van H.J.C. van Marle en J.W. Reicher, eigen uitgave, 1987.

4. Dr. S. van Mesdagkliniek, Open gesloten, onder redactie van J. Rombout, H. Siebering, A. Fekkes, e.a., eigen uitgave, 1995.

5. Dr. S. van Mesdagkliniek: Een open gesloten instelling, interne publicatie, H. Siebering, augustus 1995.

6. Projectfolders gemaakt in het kader CAP '96 en '98.

Ministerie van Justitie, VROM (Rijksgebouwendienst).

7. Het Penitentiaire Recht, uitgave Gouda Quint, losbladig systeem, band 2 , hoofdstuk $9, \S 3$ en 4 , blz. 203, e.v.

8. Dr. S. van Mesdagkiniek, Werken aan een nieuw bestaan, Informatiefolder voor patiënten en bezoek, 1998/1999

9. Dr. S. van Mesdagkliniek, artikel geschreven voor Balans, H. Greuter, 1985. 